BIOMEDICAL AND BIOSOCIAL ANTHROPOLOGY
$\begin{gathered}\text { Official Journal of the International Academy } \\ \text { of Integrative Anthropology } \\ \text { journal homepage: } \mathrm{http} / / \text { /bba-journal.com }\end{gathered}$

\title{
Sonographic model parameters of kidney in men and women endo-mesomorphic somatotype depending on the anthropometric indices characteristics
}

\section{Ustymenko O.S.}

Bogomolets National Medical University, Kyiv, Ukraine

\section{ARTICLE INFO}

Received: 1 December, 2017

Accepted: 18 January, 2018

UDC: $616-073.4-8: 616.61: 616-$ 055.1:616-055.2

\section{CORRESPONDING AUTOR}

e-mail: lena_ustimenko@rambler.ru Ustymenko O. S.
The application of the mathematical method for establishing quantitative relationships between the set of anthropometric parameters and sonographic parameters of the patient allows in some cases to significantly improve early diagnosis of diseases, make it not only timely, but accurate. The purpose of the work is to analyze the regression models of individual sonographic sizes of the kidneys in practically healthy men and women of the endo-mesomorphic somatotype, depending on the peculiarities of the structure and size of the body. Sonographic renal research conducted using ultrasonic diagnostic system "CAPASEE" SSA-220A (Toshiba, Japan). For each kidney, the length, width (transverse size) and front and rear dimensions were determined; the area of the longitudinal and transverse sections of the kidneys and their sinuses, as well as the volume of the right and left kidneys. All of them had an anthropometric survey conducted by V.V. Bunak in the modification of P. P. Shaparenko. The evaluation of the somatotype was carried out according to the mathematical scheme of J. Carter and B. Heath. Determining the absolute amount of fat, bone and muscle components of body weight was calculated by the formula J. Matiegka and the muscular component - by the formulas of the American Institute of Nutrition. For the construction of models of individual sonographic parameters of the kidneys, the method of stepwise regression analysis in the package "STATISTICA 6.1" was used. In practically healthy men and women of Podillia endo-mesomorphic somatotype of 16 possible 14 reliable regression models of sonographic parameters of the right and left kidneys, based on anthroposomatotypological indicators with a determination coefficient, from 0.767 to 0.966 and from 0.672 to 0.912 were constructed. The constructed models of sonographic parameters of both kidneys in men endo-mesomorphic somatotype most often include the circumferential body dimensions (22.4\%), cephalometric indices and the thickness of skin and fat folds (17.1\%), body diameters (14.5\%), and longitudinal body dimensions (11.8\%). The constructed models of sonographic parameters of both kidneys in women endo-mesomorphic somatotype most often include circumferential body sizes(23.1\%), body diameters (20.5\%), cephalometric indices (19.2\%) and thickness of skin and fat folds (16.7\%). In the analysis of entering into models of sonographic parameters of the kidneys anthropometric and somatotypological indicators, expressed manifestations of asymmetry and sexual dimorphism.

Keywords: regression analysis, practically healthy men and women, sonographic parameters of the kidneys, anthropometry, endo-mesomorphic somatotype.

\section{Introduction}

Sonography is a method of non-invasive study of the human body based on the piezoelectric effect. Different fabrics in their own way prevent the spread of ultrasound waves due to different acoustic resistance. Due to its safety and the absence of side effects, this method of research has become widespread in the prenatal diagnosis and diagnosis of diseases of the internal organs, in particular, the kidneys [8]. In a series of diagnostic measures for the detection of 
kidney diseases one of the leading places takes ultrasound. The findings are often critical to the tactics of further diagnostic procedures $[5,11]$

One of the most important tasks in the organization of treatment of patients with traumatic diseases and kidney diseases is individualized diagnosis, and for this purpose, knowledge of the standard morphometric parameters of this body and modeling, depending on the anthropometric indicators, are necessary. Development of endo- and angiosurgery requires detailed knowledge of the dimensional variability of the kidneys of persons of different constitutional types in certain age periods, which allows developing differential diagnostic criteria in determining the treatment tactics $[6,7,8]$.

Active studies are aimed at finding interconnections between sonographic indicators of the kidneys and anthropometric indicators among healthy, sick population, representatives of different ethnic groups, people of all ages and sex, performed by foreign researchers in recent years, indicate a high interest in this topic and its relevance $[1,3,6-9,16]$, which, together with the need to create a normative basis for ultrasound parameters of the kidneys for the population of Ukraine of different somatotypes, leads to in-depth study of this topic.

The purpose of the work is to analyze the regression models of individual sonographic sizes of the kidneys in practically healthy men and women of the endomesomorphic somatotype, depending on the peculiarities of the structure and size of the body.

\section{Materials and methods}

Within the framework of the agreement on scientific cooperation from the database of the research center of the National Pirogov Memorial Medical University, Vinnytsya taken initial sonographic parameters and anthropometric indicators 97 healthy men and almost healthy 121 women of the first mature age (21 to 35 ) that the third generation residing in Podillia region of Ukraine.

Sonographic renal research conducted using ultrasonic diagnostic system "CAPASEE" SSA-220A (Toshiba, Japan) convex transducer with an operating frequency of $3.75 \mathrm{MHz}$ and a diagnostic ultrasound system Voluson 730 Pro (Austria), 4-10 $\mathrm{MHz}$ convex transducer. For each kidney, the length, width (transverse size) and front and rear dimensions were determined; the area of the longitudinal and transverse sections of the kidneys and their sinuses, as well as the volume of the right and left kidneys.

All of them had an anthropometric survey conducted by V.V. Bunak in the modification of P. P. Shaparenko [19]. The evaluation of the somatotype was carried out according to the mathematical scheme of J. Carter and B. Heath [2]. Determining the absolute amount of fat, bone and muscle components of body weight was calculated by the formula J. Matiegka [14] and the muscular component - by the formulas of the American Institute of Nutrition [20].

For the construction of models of individual sonographic parameters of the kidneys, the method of stepwise regression analysis in the package "STATISTICA 6.1" was used.

\section{Results}

In the practically healthy men of the endo-mesomorphic somatotype $(n=18)$, the following reliable models of sonographic parameters of the right and left kidneys were constructed depending on the features of anthropometric and somatotypological indicators:

RE_R_DL (the length of the right kidney in the longitudinal section) $=128.4-2.220 \times \mathrm{GPPL}+2.248 \times$ GGR + $0.755 \times$ GL $-1.358 \times$ ACR + $1.837 \times$ OBPL1 -0.297 $x \times$ OBGK1 $\left(R^{2}=0.914 ; F_{(6,11)}=19.41 ; p<0.001 ;\right.$ St. Error of estimate $=1.993$ ),

where (here and in the future), GPPL - thickness of the skin-fat fold (TSFF) on the front surface of the shoulder $(\mathrm{mm})$; GGR - TSFF on chest $(\mathrm{mm})$; GL - TSFF under the shoulder blade $(\mathrm{mm})$; ACR - shoulder width $(\mathrm{cm})$; OBPL1 - girth shoulder in a tense state $(\mathrm{cm})$; OBGK1 - girth of the chest on the inhalation $(\mathrm{cm}) ; \mathrm{R}^{2}$ - coefficient of

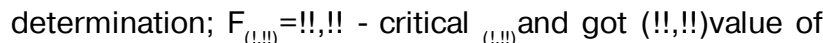
Fisher's criterion; St. Error of estimate - standard error of the standardized regression coefficient;

RE L DL (the length of the left kidney in the longitudinal section) $=48.51+0.878 \times$ ATPL $-1.565 \times$ PSG $+1.053 \times$ MA - $2.393 \times$ B_SH_GL - $1.682 \times \mathrm{OBPL}_{2}+0.925 \times$ SAG_DUG $\left(R^{2}=0.945 ; F\left({ }_{6,11}\right)=31.29 ; p<0.001 ;\right.$ St. Error of estimate $=2.420$ ),

where (here and in the future), ATPL - height of shoulder point $(\mathrm{cm})$; PSG - transverse mid-thorax size $(\mathrm{cm})$; MA muscular component of body weight by the American Institute of Nutrition $(\mathrm{kg})$; B_SH_GL - greatest head width $(\mathrm{cm}) ; \mathrm{OBPL}_{2}$ - shoulder girdle in a non-stressed state $(\mathrm{cm})$; SAG_DUG - sagittal arch of the head $(\mathrm{cm})$;

RE_R_PO (width of the right kidney in the longitudinal section $)=2.267+0.600 \times$ OBT $+0.994 \times$ MA $-1.620 \times$ ATND + $1.295 \times \mathrm{H}-0.423 \times \mathrm{OBGK}_{2}\left(\mathrm{R}^{2}=0.935 ; \mathrm{F}_{(7,9)}=18.45\right.$; $\mathrm{p}<0.001$; St. Error of estimate $=1.922$ ),

where (here and in the future), OBT - waist circumference (cm); ATND - height of the super-sternum point $(\mathrm{cm}) ; \mathrm{H}$ - body length $(\mathrm{cm}) ; \mathrm{OBGK}_{2}$ - girth of the chest on exhalation $(\mathrm{cm})$;

RE_L_PO (the width of the left kidney in the longitudinal section) $=55.45+0.830 \times$ PSG $-3.522 \times$ B_DL_GL + $2.440 \times$ SH_N_CH $+2.618 \times \mathrm{OBPR}_{2}-0.319 \times$ ATP -0.773 $x$ GGL $\left(R^{2}=0.958 ; F_{(6,11)}=42.31 ; p<0.001\right.$; St. Error of estimate $=1.584)$,

where (here and in the future), B_DL_GL - greatest head length (cm); SH_N_CH - mandibular width $(\mathrm{cm})$; $\mathrm{OBPR}_{2}$ forearm girth in the lower third $(\mathrm{cm})$; ATP - finger point height (cm); GGL - TSFF on the shin $(\mathrm{mm})$; 
RE_R1SRE (area of the longitudinal section of the right kidney) $=116.1+1.533 \times$ MA $-2.656 \times$ SGK $-0.677 \times$ ATP $-1.800 \times$ ACR + $1.646 \times$ SAG_DUG - $1.428 \times$ GGR $\left(R^{2}=0.887\right.$; $F_{(6,11)}=14.43 ; p<0.001 ;$ St. Error of estimate=2.815),

where (here and in the future), SGK - anterior-posterior chest size $(\mathrm{cm})$;

RE_R2SRE (square cross section of the right kidney) = $16.55+0.482 \times$ MA $-0.487 \times$ ATP $+2.323 \times$ N_SH_GL + $1.147 \times$ SGK $-0.356 \times$ OBGK $_{2}\left(R^{2}=0.767 ; F_{(5,12)}=7,89 ; p<0.01\right.$; St. Error of estimate $=2,318)$,

where (here and in the future), N_SH_GL - minimum width of the head $(\mathrm{cm})$;

RE_L1SRE (area of the longitudinal section of the left kidney) $=215.5+2.641 \times$ MA $-5.301 \times$ B DL GL - $3.292 \times$ $\mathrm{OBPL}_{1}-1.650 \times \mathrm{SGK}-0.867 \times \mathrm{PSG}+0.346 \times \mathrm{GG}\left(\mathrm{R}^{2}=0.938\right.$; $F_{(6,11)}=27.55 ; p<0.001 ;$ St. Error of estimate=2.254),

where (here and in the future), GG - TSFF on the abdomen $(\mathrm{mm})$;

RE_L2SRE (cross-sectional area of the left kidney) = $-10.60+0.373 \times \mathrm{MM}+0.717 \times \mathrm{SGK}-0.516 \times \mathrm{GBD}+1.773$ $x$ EPPL $-0.352 \times$ SPIN + 1.160 x EPB $\left(R^{2}=0.966 ; F_{(6,11)}=52.20\right.$; $\mathrm{p}<0.001$; St. Error of estimate $=0.481$ ),

where (here and in the future), MM - muscle mass component by Matiegka (kg); GBD - TSFF on the thigh ( $\mathrm{mm}$ ); EPPL - width of the distal epiphysis (WDE) of the shoulder $(\mathrm{cm})$; SPIN - interstitial distance of pelvis $(\mathrm{cm})$; EPB - WDE of hip (cm);

RE_R1SSI (area of the longitudinal section of the sinus of the right kidney) $=2.124+0.954 \times \mathrm{SH} N \mathrm{~N} \_\mathrm{CH}-0.777 \mathrm{x}$ ATP $-0.962 \times$ GPPL $+0.845 \times$ ATL $+1.709 \times \mathrm{MX}-0.855 \times$ OBS $\left(R^{2}=0.918 ; F_{(6,11)}=20.53 ; p<0.001\right.$; St. Error of estimate $=1.151$,

where (here and in the future), ATL - height of pubic point $(\mathrm{cm})$; MX - mesomorphic component of the somatotype according to Hit-Carter (score); OBS - foot circumference $(\mathrm{cm})$;

RE_R2SSI (square cross section of the sinus of the right kidney) $=-849.5-17.36 \times \mathrm{GZPL}+101.4 \times \mathrm{OBSH}-210.1 \mathrm{x}$ $\mathrm{EPG}+19.96 \times \mathrm{GL}-10.31 \times \mathrm{OBGK}_{1}\left(\mathrm{R}^{2}=0.909 ; \mathrm{F}_{(5,12)}=23.98\right.$; $p<0.001$; St. Error of estimate $=58.04)$,

where (here and in the future), GZPL - TSFF on the back of the shoulder $(\mathrm{mm})$; OBSH - neck circumference $(\mathrm{cm})$; EPG - WDE of shin $(\mathrm{cm})$;

RE_L1SSI (the area of the longitudinal section of the sine of the left kidney) $=83.84+1.469 \times \mathrm{MA}-2.528 \times \mathrm{OBPL}_{1}$ -
$2.491 \times$ B_DL_GL + $0.298 \times$ ATV $-0.776 \times$ SGK $\left(R^{2}=0.881\right.$; $F_{(5,11)}=17.81 ; p<0.001 ;$ St. Error of estimate=1.749),

where (here and in the future), ATV - height of the swivel point $(\mathrm{cm})$;

RE_L2SSI (square cross section of the sinus of the left kidney) $=-66.21+28.37 \times \mathrm{OBSH}+46.75 \times \mathrm{SH} \mathrm{N} \_\mathrm{CH}-$ $48.51 \times$ N_SH_GL + $16.39 \times$ GZPL - $15.34 \times$ OBS $\left(R^{2}=0.846\right.$; $F_{(5,12)}=13.16 ; p<0.001 ;$ St. Error of estimate=39.71);

RE_R_VRE (volume of the right kidney) $=90.09+5.063$ x MA + $2.421 \times$ OBT $-3.274 \times$ OBGK2 $-2.596 \times$ ATP + $11.07 \times$ N_SH_GL $\left(R^{2}=0.866 ; F\left({ }_{5,12}\right)=15,52 ; p<0,001\right.$; St. Error of estimate=13.67);

RE_L_VRE (volume of the left kidney) $=-238.7+5.740 x$ OBBB - $3.576 \times \mathrm{GB}+2.712 \times \mathrm{GL}-8.512 \times$ B_DL_GL $\left(R^{2}=0.847 ; F_{(4,13)}=18.05 ; p<0.001 ;\right.$ St. Error of estimate=10.95).

where (here and in the future), OBBB - hips circumference (cm); GB - TSFF on the side (mm).

In the practically healthy women of the endomesomorphic somatotype $(n=24)$, the following reliable models of sonographic parameters of the right and left kidneys were constructed, depending on the features of the anthropometric and somatotypological parameters:

RE_L_DL (the length of the left kidney in the longitudinal section) $=-11.67+2.735 \times \mathrm{TROCH}-5.558 \times \mathrm{B} \mathrm{SH} \mathrm{GL}+$ $1.226 \times \mathrm{OBT}-1.778 \times \mathrm{MM}+7.200 \times \mathrm{EPG}+1.410 \times \mathrm{PNG}$ $\left(R^{2}=0.906 ; \quad F_{(6,15)}=24.07 ; p<0.001 ;\right.$ St. Error of estimate $=2.400$ ),

where (here and in the future), TROCH - inter-swivel distance of the pelvis $(\mathrm{cm})$; PNG - lower thoracic transverse size $(\mathrm{cm})$;

RE_R_PO (width of the right kidney in the longitudinal section) $=50.17-2.355 \times$ GPPL $+1.575 \times$ SPIN $-2.686 \times$ $\mathrm{CONJ}+0.843 \times \mathrm{GL}-1.233 \times \mathrm{SGK}+0.416 \times \mathrm{OBT}\left(\mathrm{R}^{2}=0.902\right.$; $F_{(6,15)}=23.01 ; p<0.001$; St. Error of estimate $\left.=2.115\right)$,

where (here and in the future), CONJ - pelvic external conjugate $(\mathrm{cm})$;

RE_L_PO (the width of the left kidney in the longitudinal section $)=77.60+3.138 \times$ N_SH_GL $-0.915 \times$ GZPL -3.935 x B_SH_GL $+0.789 \times$ SPIN $-0.240 \times$ ATL $\left(R^{2}=0.807\right.$; $F_{(5,16)}=13.34 ; p<0.001 ;$ St. Error of estimate=2.228);

RE_R_TO (anterior-posterior size of the right kidney on a cross-section) $=-129.3+0.626 \times \mathrm{PSG}+1.917 \times \mathrm{OBSH}-$ $0.754 \times$ ATL $+1.714 \times$ SAG_DUG $+4.372 \times$ B_SH_GL +26.29 $x S\left(R^{2}=0.809 ; F_{(6,15)}=10.58 ; p<0.001 ;\right.$ St. Error of estimate $=2.502$ ), 
where (here and in the future), S - body surface area $\left(\mathrm{m}^{2}\right)$;

RE_L_TO (anterior-posterior size of the left kidney on a cross-section) $=81.92+1.491 \times$ OBS $-0.765 \times$ ATL +0.209 x GG + $2.678 \times$ OM $-0.591 \times$ GZPL $-1.862 \times$ N_SH_GL $\left(R^{2}=0.840 ; F_{(6,14)}=12.23 ; p<0.001 ;\right.$ St. Error of estimate=1.545),

where (here and in the future), GG - TSFF on the abdomen $(\mathrm{mm})$; OM - bone component of body weight by Matiegka $(\mathrm{kg})$;

RE_R1SRE (area of the longitudinal section of the right kidney) $=201.1-2.552 \times$ SGK $-1.782 \times$ GPPL $+1.076 \times$ GL - 4.766 x OBK - $1.407 \times$ OB_GL + $1.882 \times$ OBS $\left(R^{2}=0.752\right.$; $F_{(6,15)}=7.58 ; p<0.001 ;$ St. Error of estimate=2.999),

where (here and in the future), OBK - brush circumference $(\mathrm{cm})$; OB_GL - head circumference $(\mathrm{cm})$;

RE_R2SRE (square cross section of the right kidney) = $40.95+1.239 \times$ N_SH_GL + $1.039 \times$ SAG_DUG $-0.822 \times$ $\mathrm{GGR}+1.059 \times \mathrm{CONJ}-2.580 \times \mathrm{MX}+1.806 \times \mathrm{FX}\left(\mathrm{R}^{2}=0.805\right.$; $F_{(6,14)}=9.64 ; p<0.01 ;$ St. Error of estimate $\left.=1.277\right)$,

where (here and in the future), FX - endomorphic component of the somatotype according to Hit-Carter (score);

RE_L1SRE (area of the longitudinal section of the left kidney) $=-3.634+1.258 \times$ PNG $+1.280 \times$ OBS $-0.976 \times$ GPPL $+1.659 \times \mathrm{TROCH}-2.950 \times$ B SH GL $-0.291 \times$ OBB $\left(R^{2}=0.912 ; F_{(6,14)}=24.08 ; p<0.001 ;\right.$ St. Error of estimate $=1.442$ ),

where (here and in the future), OBB - hip circumference $(\mathrm{cm})$;

RE_L2SRE (cross-sectional area of the left kidney) $=3.414$ $+1.480 \times$ OBS $-0.483 \times$ ATL $+0.330 \times$ MA $+1.623 \times$ EPB $+0.468 \times$ TROCH $-0.216 \times$ OBT $\left(R^{2}=0.881 ; F_{(6,14)}=17.28\right.$; $\mathrm{p}<0.001$; St. Error of estimate $=0.871)$;

RE R2SSI (square cross section of the sinus of the right kidney) $=126.9+54.19 \times$ SH_LICA $-40.14 \times$ OBS $+3.34 \times$ OBSH - $30.70 \times$ SGK $\left(R^{2}=0.672 ; F_{(4,16)}=8.18 ; p<0.001\right.$; St. Error of estimate $=67.58)$, $(\mathrm{cm})$

where (here and in the future), SH LICA - face width

RE_L1SSI (the area of the longitudinal section of the sine of the left kidney) $=-17.47+0.863 \times \mathrm{PNG}+1.371 \times \mathrm{OBPR}_{2}+$ $0.506 \times$ GBD $-0.850 \times$ GGL $+1.522 \times \mathrm{MX}-0.483 \times \mathrm{OBPL}_{2}$ $\left(R^{2}=0.909 ; F_{(6,14)}=23.28 ; p<0.001 ;\right.$ St. Error of estimate $\left.=0.767\right)$

RE L2SSI (square cross section of the sinus of the left kidney) $=-2099-18.52 \times$ GZPL $+46.01 \times$ OBS $+37.16 \times$
SAG_DUG $-8.160 \times$ ATP $+29.88 \times$ OBPL $_{1}+23.99 \times$ SH_N_CH $\left(R^{2}=0.871 ; F_{(6,14)}=15.76 ; p<0.001 ;\right.$ St. Error of estimate $=44.40$ );

RE_R_VRE (volume of the right kidney) $=-480.9+11.96$ x N_SH_GL $+4.424 \times$ SPIN $-2.699 \times$ ATV $+8.291 \times$ OBSH $+5.603 \times$ SAG_DUG + $5.998 \times$ OBS $\left(R^{2}=0.849 ; F_{(6,15)}=14.06\right.$; $\mathrm{p}<0.001$; St. Error of estimate $=10.82$ );

RE_L_VRE (volume of the left kidney) $=-302.6-9.322$ $\times \mathrm{GPPL}+39.93 \times \mathrm{EPPL}+14.28 \times \mathrm{EPB}+2.448 \times \mathrm{SPIN}+$ $2.321 \times$ SAG_DUG $\left(R^{2}=0.801 ; F_{(5,15)}=12.10 ; p<0.001\right.$; St. Error of estimate $=9.767)$.

\section{Discussion}

Obtaining the most objective information about a particular patient, reducing the proportion of subjectivity, the importance of personality factors in the work of the doctor are features of modern requirements to the doctor in terms of differential diagnosis of pathology of internal organs $[10,12,13]$. In turn, the information obtained is the basis for the elaboration of a complex of adequate medical treatment. This process has so far been performed by the doctor himself without the use of any special devices that facilitate the processing of information, while taking a significant part of the working time.

The use of a mathematical method for establishing quantitative relationships between a set of anthropometric parameters and sonographic parameters of a patient allows in some cases to significantly improve early diagnosis of diseases, make it not only timely, but also accurate $[15,18]$. In view of the above, it is necessary to conduct a diagnostic ultrasound examination of the kidneys and to apply the methods of mathematical modeling and multidimensional statistics for the creation of a practically significant model of the body that manifests the relationship between factors such as total, longitudinal, transverse, circumferential dimensions, TSFF and others [17].

Thus, in men of the endo-mesomorphic somatotype of 16 possible regression models were constructed 14 sonographic parameters of the left and right kidneys, depending on anthropometric and somatotypological with indices $\mathrm{R}^{2}$ from 0.776 to 0.966 . In reliable models, the anterior-posterior size of the right and left kidneys on the transverse section of $R^{2}$ is less than 0.6 (respectively, 0.528 and 0.597 ) and therefore they are not essential for practical medicine.

The constructed models of sonographic parameters of both kidneys in men of the endo-mesomorphic somatotype most often include circumferential body dimensions (22.4\%), cephalometric indices and TSFF (by $17.1 \%$ ), body diameters $(14.5 \%)$ and longitudinal body sizes (11.8\%). Among the individual anthropometric and somatotypological parameters of the body models most often include the muscle component of the body weight by the American Institute of Nutrition (up to 7 models), the height of the finger point and the anteriorposterior size of the chest (up to 5 models). 
The constructed models of sonographic parameters of the right kidney in men of the endo-mesomorphic somatotype most often include circumferential body dimensions (26.3\%), TSFF (18.4\%) and longitudinal body sizes (15.8\%). Among the individual anthropometric and somatotypological parameters of the body models most often include the height of the finger point, the muscle component of the body weight at the American Institute of Nutrition (up to 4 models), the girth of the chest on exhalation (up to 3 models).

The models of sonographic parameters of the left kidney in men of the endo-mesomorphic somatotype most often include cephalometric indices (23.7\%), diameters and girths of the body (by 18.4\%) and TSFF (15.8\%). Among the individual anthropometric and somatotypological parameters of the body, models most often include the largest length of the head (up to 4 models), transverse mid-thoracic size, anterior-posterior chest size, muscle mass component of the American Institute of Nutrition (up to 3 models).

Thus, for women of the endo-mesomorphic somatotype, as for men, from 16 possible, 14 models of sonographic parameters for the left and right kidneys, based on anthropometric and somatotypological indices with $\mathrm{R}^{2}$ from 0.672 to 0.912 , were constructed. In reliable models, the length of the right kidney in the longitudinal section and the square of the longitudinal section of the right side of the right kidney $R^{2}$ is less than 0.6 (respectively, 0.385 and 0.191 ) and therefore they do not matter for practical medicine.

The constructed models of sonographic parameters of both kidneys in women of the endo-mesomorphic somatotype most often include circumferential body dimensions (23.1\%), body diameters $(20.5 \%)$, cephalometric indexes (19.2\%), and TSFF (16.7\%). Among the individual anthropometric and somatotypological parameters of the body, models most often include the circumference of the foot (up to 7 models), sagittal arc of the head (up to 5 models), the largest head width, the height of the pubic point, the interstitial distance of the pelvis, and the TSFF on the front surface of the shoulder (up to 4 models).

The constructed models of sonographic parameters of the right kidney in women of the endo-mesomorphic somatotype most often include cephalometric indices, body diameters, and circumferential body sizes (by 24.2\%). Among individual anthropometric and somatotypological parameters of the body models most often include sagittal arc of the head, anterior-posterior size of the chest, foot circumference and neck circumcision (up to 3 models).

The constructed models of sonographic parameters of the left kidney in women of the endo-mesomorphic

\section{References}

[1] Bakker, H., Kooijman, M. N., van der Heijden, A. J., Hofman, A., Franco, O. H., Taal, H. R., \& Jaddoe, V. W. (2014). Kidney size and function in a multi-ethnic population-based cohort of school-age children. Pediatr Nephrol., 29(9), 1589-1598. DOI: $10.1007 / \mathrm{s} 00467-014-2793-8$. somatotype most often include the circumferential dimensions of the body (22.2\%), body diameters and TSFF (by $17.8 \%$ ), and cephalometric indices (15.6\%). Among the individual anthropometric and somatotypological parameters of the body, models most often include the circumference of the foot (up to 4 models), the height of the pubic point, the transverse lower thorax size, inter-swivel distance of the pelvis and TSFF on the back of the shoulder (up to 3 models).

Comparing the results obtained with previous studies in men and women of the mesomorphic somatotype [4, 21], it should be noted that among the representatives of the mesomorphic somatotype of 16 possible sonographic models of the kidney, only 7 models with $\mathrm{R}^{2}$ greater than 0,6 were constructed (respectively $0.615-0.715$ and 0.607 - 0.641). The constructed models of sonographic parameters of both kidneys in women of the mesomorphic somatotype most often included the circumferential dimensions of the body $(29.8 \%)$ and cephalometric indices (19.1\%), and in men the mesomorphic somatotype - the circumferential dimensions of the body (23.9\%), the diameters body (19.6\%), TSFF and WDE long limb bones (by 15.2\%).

Thus, the use of mathematical modeling in ultrasound diagnostics will facilitate early and complete detection of diseases of the organs of the urinary system, reducing the number of workers disability as a result of timely initiated and adequate therapy, rational use of expensive equipment. It seems likely that the use of mathematical modeling methods will provide significant assistance in the therapeutic and surgical service and specialist doctors in the process of differential diagnosis of kidney diseases and dynamic monitoring of patient data.

\section{Conclusions}

1. In practically healthy men and women of endomesomorphic somatotype of 16 possible sonographic parameters of the right and left kidneys, based on anthropometric and somatotypological indicators, were constructed by 14 reliable models with $R^{2}$ from 0.776 to 0.966 and from 0.672 to 0.912 .

2 . The models that were built for men of endomesomorphic somatotype most often include: for the right kidney - the circumferential dimensions of the body (26.3\%), TSFF (18.4\%) and longitudinal body sizes (15.8\%); for the left kidney - cephalometric indices (23.7\%), diameters and girths of the body (by 18.4\%) and TSFF (15.8\%).

3. Women's of endo-mesomorphic somatotype models most often include: for the right kidney - cephalometric indices, body diameters and circumferential body sizes (by 24.2\%); for the left kidney - girths of the body (22.2\%), body diameters and TSFF (by $17.8 \%$ ), cephalometric indices (15.6\%).

[2] Carter, J. L., \& Heath, B. H. (1990). Somatotyping development and applications. Cambridge University Press. ISSN 0957-0306.

[3] Chen, S., Wu, B., Liu, X., Chen, Y., Li, Y., Li, M., ... Zou, H. (2013). Association of Anthropometric indexes with chronic 
kidney disease in a Chinese population. Clin Nephrol., 80(5), 361-369. doi: 10.5414/CN108002.

[4] Cherkasov, V. G., \& Ustymenko, O. S. (2017). Modeling using regression analysis of sonographic parameters of kidneys depending on the features of the size of practical healthy women with mesomorphic somatotype. World of Medicine and Biology, 3(61), 73-76.doi: 10.26724/20798334-2017-3-61-73-76.

[5] Correas, J. M., Anglicheau, D., Joly, D., Gennisson, J. L., Tanter, M., \& Hélénon, O. (2016). Ultrasound-based imaging methods of the kidney-recent developments. Kidney Int., 90(6), 1199-1210. doi: 10.1016/j.kint.2016.06.042.

[6] Hyun, Y. Y., Lee, K. B., Rhee, E. J., Park, C. Y., Chang, Y., \& Ryu, S. (2016). Chronic kidney disease and high eGFR according to body composition phenotype in adults with normal BMI. Nutr. Metab. Cardiovasc., 26(12), 1088-1095. doi: 10.1016/j.numecd.2016.09.003.

[7] Johansen, K. L., \& Lee, C. (2015). Body composition in chronic kidney disease. Curr. Opin. Nephrol. Hypertens., 24(3), 268275. doi: $10.1097 / \mathrm{MNH} .0000000000000120$.

[8] Jaroszynski, A., Dereziński, T., Jaroszyńska, A., Zapolski, T., Wąsikowska, B., Wysokiński, A., ... Horoch, A. (2016). Association of anthropometric measures of obesity and chronic kidney disease in elderly women. Ann. Agric. Environ. Med., 23(4), 636-640. doi: https://doi.org/10.5604/ 12321966.1226859.

[9] Jovanović, D., Gasic, B., Pavlovic, S., \& Naumovic, R. (2013). Correlation of kidney size with kidney function and anthropometric parameters in healthy subjects and patients with chronic kidney diseases. Ren Fail., 35(6), 896-900. doi: 10.3109/0886022X.2013.794683.

[10] Kalloo, S. D., Mathew, R. O., \& Asif, A. (2016). Is nephrology specialty at risk? Kidney Int., 90(1), 31-33. doi: 10.1016/ j.kint.2016.01.032.

[11] Niyyar, V. D.,\& O'Neill W. C. (2018). Point-of-care ultrasound in the practice of nephrology. Kidney Int., 93(5), 1052-1059. doi: 10.1016/j.kint.2017.11.032.

[12] Mackinnon, B., McKinlay, J., McQuarrie, E., \& Geddes, C. (2010). Early ultrasound to detect complications after renal biopsy. Nephrol. Dial. Transplant., 25(1), 316-317. doi: 10.1093/ndt/gfp540.

[13] Manley, J. A., \& O'Neill, W. C. (2001). How echogenic is echogenic? Quantitative acoustics of the renal cortex. Am. J. Kidney Dis., 37(4), 706-711. PMID: 11273869.

[14] Matiegka, J. (1921). The testing of physical effeciecy. Amer. J. Phys. Antropol., 2(3), 25-38. https://doi.org/10.1002/ ajpa. 1330040302.

[15] O'Neill, W. C., Bardelli, M., \& Yevzlin, A. S. (2011). Imaging for renovascular disease. Semin. Nephrol., 31(3), 272-282. doi: 10.1016/j.semnephrol.2011.05.007.

[16] Pietrzak-Nowacka, M., Safranow, K., Palacz, J., Gołembiewska, E., Marchelek-Myśliwiec, M., \& Ciechanowski, K. (2015). Association of kidney and cysts dimensions with anthropometric and biochemical parameters in patients with ADPKD. Ren Fail., 37(5), 798-803. doi: 10.3109/0886022X.2015.1033608.

[17] Quaia, E, Nocentini, A, \& Torelli L. (2009). Assessment of a new mathematical model for the computation of numerical parameters related to renal cortical blood flow and fractional blood volume by contrast-enhanced ultrasound. Ultrasound Med. Biol., 35(4), 616-627. doi: 10.1016/ j.ultrasmedbio.2008.10.003.

[18] Salsberg, E., Quigley, L., Masselink, L., Wu, X., \& Collins, A. (2015). The US Nephrology Workforce 2015: Developments and Trends. American Society of Nephrology. https:// www.asn-online.org.

[19] Shaparenko, P. P. (2000). Antropometriya. Vinny`cya: [w.p.].

[20] Shephard, R. J. (1991). Body composition in biological anthropology. Cambridge. ISBN-10: 0521362679.

[21] Ustymenko, O. S. (2017). Regression models of sonographic parameters of kidneys in men of mesomorphic somatotype in connection with the features of size of the body. Biomedical and biosocial anthropology, 28, 106-108.

\section{Устименко О. С. \\ МОДЕЛІ СОНОГРАФІЧНИХ ПАРАМЕТРІВ НИРОК У ЧОЛОВІКІВ І ЖІНОК ЕНДО-МЕЗОМОРФНОГО СОМАТОТИПУ В ЗАЛЕЖНОСТІ ВІД ОСОБЛИВОСТЕЙ АНТРОПОМЕТРИЧНИХ ПОКАЗНИКІВ}

Застосування математичного методу для встановлення кількісних взаємозв'язків між набором антропометричних параметрів і сонографічних показників пацієнта дозволяє в ряді випадків значно покращити ранню діагностику захворювань, зробити ї̈ не тільки своєчасною, але й точною. Мета роботи - провести аналіз регресійних моделей індивідуальних сонографічних розмірів нирок у практично здорових чоловіків і жінок ендо-мезоморфного соматотипу в залежності від особливостей будови і розмірів тіла. Сонографічне дослідження нирок проведено за допомогою ультразвукової діагностичної системи "CAPASEE" SSA-220A (Toshiba, Японія). Для кожної нирки визначали: довжину, ширину (поперечний розмір) і передньо-задній розміри; площі поздовжнього та поперечного перерізу нирок та їх синусів, а також об'єм правої і лівої нирок. Усім їм було проведено антропометричне обстеження за В. В. Бунаком у модифікації П. П. Шапаренка. Оцінку соматотипу проводили за математичною схемою J. Carter i B. Heath. Визначення абсолютної кількості жирового, кісткового і м'язового компонентів маси тіла розраховували за формулами J. Matiegka, а також м'язовий компонент - за формулами Американського інституту харчування. Для побудови моделей індивідуальних сонографічних параметрів нирок був застосований метод покрокового регресійного аналізу в пакеті "STATISTICA 6.1". у практично здорових чоловіків і жінок Поділля ендо-мезоморфного соматотипу із 16 можливих побудовані по 14 достовірних регресійних моделі сонографічних параметрів правої і лівої нирки в залежності від антропо-соматотипологічних показників із коефіціентом детермінації відповідно від 0,767 до 0,966 та від 0,672 до 0,912. До побудованих моделей сонографічних параметрів обох нирок у чоловіків ендо-мезоморфного соматотипа найчастіше входять обхватні розміри тіла (22,4\%), кефалометричні показники і товщина шкірно-жирових складок (по 17,1\%), діаметри тіла (14,5\%) і поздовжні розміри тіла (11,8\%). До побудованих моделей сонографічних параметрів обох нирок у жінок ендомезоморфного соматотипа найчастіше входять обхватні розміри тіла (23, 1\%), діаметри тіла (20,5\%), кефалометричні показники (19,2\%) і товщина шкірно-жирових складок (16,7\%). При аналізі входження до моделей сонографічних параметрів нирок антропометричних і соматотипологічних показників встановлені виражені прояви асиметрії і статевого диморфізму.

Ключові слова: регресійний аналіз, практично здорові чоловіки і жінки, сонографічні параметри нирок, антропометрія, ендо-мезоморфний соматотип. 
Устименко А. С. МОДЕЛИ СОНОГРАФИЧЕСКИХ ПАРАМЕТРОВ ПОЧЕК У МУЖЧИН И ЖЕНЩИН ЭНДО-МЕЗОМОРФНОГО СОМАТОТИПА В ЗАВИСИМОСТИ ОТ ОСОБЕННОСТЕЙ АНТРОПОМЕТРИЧЕСКИХ ПОКАЗАТЕЛЕЙ

Применение математического метода для установления количественных взаимосвязей между набором антропометрических параметров и сонографических показателей пациента позволяет в ряде случаев значительно улучшить раннюю диагностику заболеваний, сделать ее не только своевременной, но и точной. Цель работы - провести анализ регрессионных моделей индивидуальных сонографических размеров почек у практически здоровых мужчин и женщин эндо-мезоморфного соматотипа в зависимости от особенностей строения и размеров тела. Сонографическое исследования почек проведено с помощью ультразвуковой диагностической системы "CAPASEE" SSA-220A (Toshiba, Япония). Для каждой почки определяли: длину, ширину (поперечный размер) и передне-задний размеры; площади продольного и поперечного сечения почек и их синусов, а также объем правой и левой почек. Всем им было проведено антропометрическое обследования по В. В. Бунаку в модификации П. П. Шапаренка. Оценку соматотипа проводили по математической схеме J. Саrter и B. Неаth. Определение абсолютного количества жировой, костной и мышечной компонентов массы тела рассчитывали по формулам Ј. Матіеgkа, а также мышечный компонент - по формулам Американского института питания. Для построения моделей индивидуальных сонографических параметров почек был применен метод пошагового регрессионного анализа в пакете"STATISTICA 6.1". У практически здоровых мужчин и женщин Подолья эндо-мезоморфного соматотипа из 16 возможных построены по 14 достоверных регрессионных моделей сонографических параметров правой и левой почки в зависимости от антропосоматотипологических показателей с коэффициентом детерминации соответственно от 0,767 до 0,966 и от 0,672 до 0,912. К построенным моделям сонографических параметров обеих почек у мужчин эндо-мезоморфного соматотипа чаще всего входят обхватные размеры тела (22,4\%), кефалометрические показатели и толщина кожно-жировых складок (по 17,1\%), диаметры тела (14,5\%) и продольные размеры тела (11,8\%). К построенным моделям сонографических параметров обеих почек у женщин эндо-мезоморфного соматотипа чаще всего входят обхватные размеры тела (23,1\%), диаметры тела (20,5\%), кефалометрические показатели (19,2\%) и толщина кожно-жировых складок (16,7\%). При анализе вхождения к моделям сонографических параметров почек антропометрических и соматотипологических показателей установлены выраженные проявления асимметрии и полового диморфизма.

Ключевые слова: регрессионный анализ, практически здоровые мужчины и женщины, сонографические параметры почек, антропометрия, эндо-мезоморфный соматотип. 